\title{
KEARIFAN LOKAL MASYARAKAT ADAT KAMPUNG NAGA SEBAGAI PENGUATAN PENDIDIKAN KARAKTER BERBASIS MASYARAKAT
}

\author{
Shilmy Purnama \\ Prodi Pendidikan Pancasila dan Kewarganegaraan, FKIP, Universitas Tanjungpura, Pontianak \\ e-mail korespondensi: shilmypurnama@ fkip.untan.ac.id
}

\begin{abstract}
Abstrak : Pembentukan karakter bangsa sudah diamanatkan melalui Pendidikan di persekolahan setiap jenjang, akan tetapi pada pelaksanaannya kurang memberikan hasil yang optimal. Program Penguatan Pendidikan Karakter yang dirancang pemerintah, difokuskan pada tiga kegiatan utama, diantaranya Penguatan Pendidikan Karakter Berbasis Kelas, Penguatan Pendidikan Karakter Berbasis Masyarakat, dan Penguatan Pendidikan Karakter Berbasis Sekolah. Penguatan Pendidikan Karakter Berbasis Masyarakat dimaksudkan untuk mendukung dan memperkuat Pendidikan karakter yang telah diberikan di kelas dan sekolah. Penelitian ini membahas kearifan lokal yang masih dianut oleh masyarakat adat Kampung Naga sebagai Penguatan Pendidikan Karakter Berbasis Masyarakat. Dalam penelitian ini, menggunakan pendekatan kualitatif dengan metode deskriptif. Teknik pengumpulan data berupa obervasi, wawancara, dan studi dokumentasi. Analisis data berdasarkan Miles \& Huberman (2014), berupa pengumpulan data, reduksi data, penyajian data, dan penarikan kesimpulan. Hasil penelitian menunjukkan bahwa masyarakat adat Kampung Naga dalam kehidupannya seharihari mencerminkan nilai-nilai karakter utama yang termuat dalam Penguatan Pendidikan Karakter. Nilai-nilai karakter tersebut diantaranya religius, nasionalis, gotong royong, mandiri, integritas, dan gotong royong. Perwujudan nilai-nilai karakter ini dapat dilihat pada kehidupan mereka, baik secara fisik (bentuk rumah, pakaian, dan perabotan), sosial (kehidupan interaksi sosial, kerja sama, sistem musyawarah), dan budaya (kesenian dan peringatan upacara tertentu). Oleh karena itu, masyarakat adat Kampung Naga dapat dijadikan mitra sekolah sebagai sumber pembelajaran Penguatan Pendidikan Karakter Berbasis Masyarakat.
\end{abstract}

Kata kunci: Penguatan Pendidikan Karakter, Kearifan Lokal, Masyarakat Adat

\begin{abstract}
The formation of national character which is mandated through education in schools at every level, but in its implementation has not given optimal results. The Strengthening Character Education Program designed by the government focuses on three main activities, namely Strengthening Class-Based Character Education, Strengthening Community-Based Character Education, and Strengthening School-Based Character Education. Strengthening Community-Based Character Education is intended to support and strengthen the character education that has been given in classrooms and schools. This study discusses local wisdom that is still adhered to by the indigenous people of Kampung Naga as a reinforcement for community-based character education. This study uses a qualitative approach with descriptive methods. Data collection techniques are observation, interview, and documentation study. Data analysis is based on Miles \& Huberman (2014), in the form of data collection, data reduction, data presentation, and drawing conclusions. The results showed that the indigenous people of Kampung Naga reflect the main character values contained in Character Strengthening Education. These character values include religion, nationalism, cooperation, independence, integrity and cooperation. The manifestation of these character values can be seen in their lives, both physically (in the form of houses, clothes and furniture), social (life of social interaction, cooperation, deliberation system), and culture (certain arts and ceremonies). warning). Therefore, the indigenous people of Kampung Naga can be used as school partners as a learning resource for Strengthening Community-Based Character Education.
\end{abstract}

Keywords: Strengthening Character Education, Local Wisdom, Indigenous Peoples. 


\section{PENDAHULUAN}

Pembangunan karakter bangsa telah termuat dalam konstitusi negara Indonesia, salah satunya melalui proses pembelajaran di persekolahan yang ingin membentuk karakter peserta didik yang cerdas intelektual dan berakhlak mulia. Upaya ini pun semakin didukung oleh pemerintah, khususnya mulai tahun 2010 dengan dirumuskannya Pedoman Pendidikan Budaya dan Karakter Bangsa oleh Badan Penelitian dan Pengembangan dengan Kementerian Pendidikan Nasional dan Menteri Koordinator Kesejahteraan Rakyat. Tujuannya adalah untuk dijadikan pedoman atau rujukan praktis yang digunakan oleh para pendidik dan tokoh atau praktisi Pendidikan dalam mengimplementasikan program Pendidikan berbasis karakter baik di kelas maupun di sekolah.

Presiden Joko Widodo dan Jusuf Kalla didukung dengan adanya nawacita pada bidang Pendidikan. Dalam nawacita ini ditegaskan bahwa pemerintah borkomitmen untuk melakukan revolusi karakter bangsa. Revolusi karakter bangsa yang dimaksud sejatinya dilakukan melalui jalur Pendidikan di persekolahan jenjang Pendidikan dasar sampai Pendidikan tinggi. Hal ini didukung pula dengan berlakunya Peraturan Presiden Republik Indonesia Nomor 87 Tahun 2017 tentang Penguatan Pendidikan Karakter sekaligus dengan dikeluarkannya buku pedoman Penguatan Pendidikan karakter oleh Pusat Analisis dan Sinkronisasi Kementerian Pendidikan dan Kebudayaan Tahun 2017.

Meskipun pembentukan karakter bangsa sudah diamanatkan melalui Pendidikan di persekolahan setiap jenjang, akan tetapi pada pelaksanaannya kurang memberikan hasil yang optimal. Proses pembelajaran di sekolah, khususnya melalui mata pelajaran Pendidikan Agama dan Pendidikan Pancasila dan Kewarganegaraan menjadi semacam tertuduh karena kurang berhasil dalam melaksanakan tugas dan fungsinya sebagai Pendidikan nilai dan moral. Fakta di lapangan selama ini masih menunjukkan masih adanya warga negara khususnya peserta didik yang tidak memiliki karakter yang baik. Asumsi yang terjadi adalah bahwa selama ini di lapangan pelaksanan pengembangan Pendidikan karakter di persekolahan lebih menekankan pada domain kognitif, kurang mengembangkan domain afektif dan psikomotor peserta didik. Proses pembelajaran hanya dilaksanakan secara konvensional di kelas, tanpa adanya kegiatan habituasi dan melibatkan masyarakat sebagai upaya penguatan Pendidikan karakter.

Program Penguatan Pendidikan Karakter yang diamanatkan pemerintah, difokuskan pada tiga kegiatan utama, diantaranya Penguatan Pendidikan Karakter Berbasis Kelas, Penguatan Pendidikan Karakter Berbasis Sekolah, dan Penguatan Pendidikan Karakter Berbasis Masyarakat.

Pendidikan berbasis masyarakat merupakan proses pelibatan anggota komunitas atau kelompok masyarakat tertentu untuk mengemukakan persoalan dan kebutuhan, menemukan solusi, menggunakan sumber daya, dan melaksanakan rencana kegiatan pembelajaran atau keduanya. Model Pendidikan ini melibatkan masyarakat dan berakar pada kebudayaan masyarakat (Tilaar, 2000).

Penguatan Pendidikan Karakter Berbasis Masyarakat dimaksudkan untuk mendukung dan memperkuat Pendidikan karakter yang telah diberikan di kelas dan sekolah. Sekolah juga bisa berkolaborasi dengan masyarakat sekitar untuk menjadi rekan dalam rangka mewujudkan upaya pemerintah membentuk karakter bangsa. Masyarakat yang bisa dilibatkan disini adalah masyarakat dengan lingkungan yang memiliki potensi sebagai sumber pembelajaran, seperti keberadaan dan dukungan seni, budaya, tokoh masyarakat, dunia usaha, atau industri, dan orang tua. Hal ini sejalan dengan Pasal 5 Permendikbud No. 20 Tahun 2018 tentang Penguatan Pendidikan Karakter pada Satuan Pendidikan Formal, yaitu pengoptimalan penyelenggaraan Penguatan Pendidikan Karakter oleh masyarakat dilaksanakan melalui pelibatan perorangan, kelompok masyarakat, dan/atau Lembaga.

Salah satu bentuk upaya Penguatan Pendidikan Karakter Berbasis Masyarakat adalah dengan melibatkan tokoh atau kelompok masyarakat. Masyarakat adat yang masih memiliki nilai-nilai kearifan lokal bisa dijadikan mitra sekolah dalam mewujudkan program ini.

Oleh karena itu, dalam penelitian ini akan dibahas mengenai Penguatan Pendidikan Karakter, khususnya yang berbasis masyarakat 
yang dilakukan di masyarakat adat Kampung Naga Kabupaten Tasikmalaya Provinsi Jawa Barat. Pada masyarakat adat Kampung Naga ini masih memiliki kearifan lokal yang sejalan dan mendukung lima karakter utama dalam Penguatan Pendidikan Karakter. Masyarakatnya juga masih memegang teguh hukum adat dan ajaran leluhurnya, khususnya hukum adat sesuai kebudayaan Sunda. Kebudayaan pun sebaiknya berfungsi sebagai pemandu individu dan collective behavior yang dapat mengarahkan manusia menjadi lebih beradab dan memiliki rasa tanggung jawab terhadap keberlangsungan peradaban (Alwasilah, 2003).

\section{METODE}

Penelitian ini dilaksanakan dengan pendekatan kualitatif dan metode deskriptif. Proses pengumpulan data melalui observasi lapangan langsung ke lokasi Kampung Naga di Kabupaten Tasikmalaya. Untuk mengumpulkan data juga dilakukan proses wawancara kepada juru kunci atau kuncen, tokoh adat, dan masyarakat adat Kampung Naga. Selain itu, studi dokumentasi juga dilakukan untuk memperoleh data sekunder berupa dokumen, bukti arsip, dan foto-foto di lapangan.

Setelah itu, data dilakukan analisis melalui proses reduksi data untuk memilih dan memilah data mana yang relevan dengan penelitian, kemudian data akan disajikan dengan cara deskripsi hasil penelitian dan di akhir penarikan kesimpulan sesuai dengan alur analisis data menurut Miles \& Huberman (2014).

\section{HASIL DAN PEMBAHASAN \\ Hasil Penelitian}

Kampung Naga berlokasi Kabupaten Tasikmalaya, Provinsi Jawa Barat, tepatnya di Desa Neglasari, Kecamatan Salawu,. Kampung Naga berbatasan langsung dengan wilayah Kabupaten Garut. Lokasinya berada di dekat jalan raya dengan harus menuruni ratusan anak tangga hingga sampai ke pemukiman masyarakat adat. Rumah-rumah masyarakat adat ini berada di Kawasan pesawahan, bukit, dan sungai sehingga menjadi lokasi yang cukup subur.

Masyarakat adat Kmapung Naga dipimpin oleh seorang Juru Kunci yang disebut Kuncen dan bertugas sebagai pemimpin adat. Sistem pemerintahan formal pada masyarat ini hamper sama dengan masyarakat Sunda lainnya, yaitu adanya Lebe, Punduh, Ketua RT dan RW.

Seluruh masyarakat adat Kampung Naga terdaftar beragama Islam. Namun, dalam kesehariannya mereka masih melakukan beberapa kegiatan keagamaan/kepercayaan yang dipengaruhi oleh ajaran leluhur (karuhun). Misalnya dalam upacara Hajat Sasih yang masih rutin dilaksanakan dan dipercaya sama dengan perayaan hari raya agama Islam lainnya. Hal ini bisa dijadikan bukti bahwa masyarakat adat tersebut masih memegang teguh hukum adat dan ajaran leluhur. Jika ada yang tidak mematuhi ajaran leluhurnya maka akan dianggap tabu dan tidak menghormati leluhur, sehingga dikhawatirkan berakibat terjadinya hal-hal yang tidak diinginkan bagi dirinya secara pribadi, maupun secara kelompok.

Berbagai hal yang masih dianggap tabu atau pantangan atau dalam istilah Bahasa Sunda disebut pamali dilaksanakan dalam kehidupan sehari-hari. Misalnya ada larangan untuk membicarakan tentang asal-usul Kampung Naga pada hari tertentu yang merupakan hari keramat, mendatangi wilayah terlarang, pembangunan rumah, tata letak, penggunaan pakaian tertentu, dan sebagainya. Selain itu, masyarakatnya sangat mempercayai palintangan atau ketentuan waktu yang dianggap sebagai waktu yang buruk atau tabu untuk melaksanakan kegiatan tertentu, seperti pernikahan, membangun rumah, khitanan, dan upacara adat lainnya. Penentuan waktu baik dan buruk ini didasarkan pada pada penentuan hari-hari naas berikut:

a. Muharam, hari Sabtu dan Minggu tanggal 11 dan 14;

b. Safar, hari Sabtu dan Minggu tanggal 1 dan 20;

c. Maulud, hari Sabtu dan Minggu, tanggal 1 dan 15;

d. Silih Mulud, hari Senin dan Selasa, tanggal 10 dan 14;

e. Jumadil Awal, hari Senin dan Selasa, tanggal 10 dan 14;

f. Jumadil Akhir, hari Senin dan Selasa, tanggal 10-14;

g. Sya'ban, hari Rabu dan Kamis, tanggal 19 dan 20;

h. Ramadhan, hari Rabu dan Kamis, tanggal 9 dan 11;

i. Dzulqaidah, hari Jumat, tanggal 2 dan 12; dan 
Volume 12 | Number 1| April |2021, Page 30-36/ E-ISSN: 2715-1247 dan P-ISSN: 2087-84xx

j. Dzulhijjah, hari Jumat, tanggal 6 dan 20.

Bentuk rumah disini harus rumah panggung yang berbahan dsar bambu dan kayu. Daun nipah, ijuk, atau alang-alang digunakan sebagai atap rumah dan berlantaikan bambu atau papan kayu. Dalam membangun rumah pun tidak sembarangan, rumah harus menghadap ke arah utara atau selatan. Kesederhanaan kehidupan masyarakatnya bisa terlihat dari bentuk rumah yang masih tradisional tanpa cat dan tembok serta tidak disertai perabotan seperti kursi, meja, dan tempat tidur. Hal ini membuktikan bahwa masyarakat adat disini sangat menghargai lingkungan fisik dan sosial budayanya sehingga masih dilaksanakan sampai sekarang meskipun sudah memasuki zaman yang serba modern.

Sama halnya dengan kampungkampung adat lainnya, Kampung Naga pun memiliki hutan larangan sebagai hutan lindung. Hutan larangan ini digunakan untuk pemakaman bagi keturunan Kampung Naga dan hutan larangan sebagai pemegang keseimbangan alam di sekitarnya. Barang siapa yang melanggar aturan hutan tersebut, maka akan dikenakan sanksi adat.

Mata pencaharian masyarakatnya adalah petani, pedagang, pengrajin kerajian tangan, pegawai di luar lingkungan Kampung Naga. Di kampung adat ini pun memiliki lumbung padi di sebuah bangunan Bersama yang berfungsi untuk menyimpan sebagian hasil panen masyarakatnya. Cadangan hasil panen ini digunakan sebagai tabungan pangan masyarakat, sehingga jika di kemudian hari mengalami bencana lama, gagal panen, atau kelangkaan, masyarakatnya tidak akan mengalami kelaparan.

Sebagian besar ibu rumah tangga berprofesi pula sebagai pedagang dan pengrajin. Maka ketika kita mengunjungi Kampung Naga, banyak sekali rumah-rumah warga yang menjual berbagai anyaman bambu dan kerajinan tangan lainnya khas Tasikmalaya. Hal ini membuktikan bahwa masyarakatnya memiliki ide-ide kreatif dan pekerja keras dalam bekerja. Berbagai kerajinan tangan dengan macam-macam bentuk dan harga menjadi daya tarik sendiri. Kerajinan tangan ini menjadi oleh-oleh khas
Kampung Naga berupa tas, topi, peralatan rumah tangga, dan pajangan.

Masyarakat adat Kampung Naga sangat mencerminkan nilai gotong royong dalam kehidupan sehari-harinya. Dalam perayaan upacara adat, hajat, pernikahan, khitanan, pembangunan rumah, dan membersihkan lingkungan, seluruh masyarkat akan turun langsung untuk bekerja sama. Dalam suatu kegiatan biasanya para pria yang melakukan kerja sama melakukan kegiatan kasar, sedangkan para wanita atua istrinya akan bahu-membahu memasak makanan yang akan disantap Bersama. Bahan makanan pun berasal dari mengumpulkan hasil bumi bersama.

Sikap tanggung jawab pun bisa dilihat dari komitmen dan konsistensi seluruh masyarakat adat Kampung Naga yang masih mematuhi aturan hukum adatnya sekaligus hokum di negara Indonesia. Masyarakat disini pun memiliki integritas yang tinggi dalam menjaga kelestarian lingkungan fisik, social, budaya, mislanya dengan tetap memegang teguh cara hidup leluhur yang sederhana, jujur, religius, mempertahankan warisan leluhur dengan tidak menggunakan tenaga listrik.

\section{Pembahasan}

Pembangunan nilai-nilia karakter peserta didik dapat dilakukan dengan cara pembelajaran di sekolah. Akan tetapi, bukan hanya menekankan pada pengetahuan saja, namun nilai-nilai karakter yang dikembangkan harus menyangkut olah hati, olah pikir, olah raga, dan olah rasa/karsa. Character Counts Coalition sebagai A Project of The Joseph Institute of Ethics, dalam Kusnaedi (2013, hlm. 36) ada enam pilar karakter yang harus dikembangkan dalam pendidikan karakter, yaitu:

a. Trustworthiness (integritas, jujur dan loyal);

b. Fairness (pemikiran terbuka);

c. Caring (peduli dan perhatian pada keadaan);

d. Respect (menghargai dan menghormati orang lain);

e. Citizenship (sadar hukum, cinta tanah air dan patriotisme); dan

f. Responsibility (bertanggung jawab, disiplin dan etos kerja). 
Sedangkan kearifan lokal merupakan ide atau gagasan masayarakat yang dianggap memiliki nilai baik sehingga tertanam, berlaku, dan diterapkan oleh anggota masyarakat tersebut. Nilai-nilai luhur terkait kearifan lokal, diantaranya:

a. Cinta kepada Allah dan alam semesta dan isinya;

b. Tanggung jawab, mandiri, dan disiplin;

c. Jujur;

d. Hormat dan santun;

e. Kasih sayang, dan peduli;

f. Percaya diri, kerja sama, kreatif, dan pantang menyerah;

g. Keadilan dan kepemimpinan;

h. Baik dan rendah hati; dan

i. Toleransi, persatuan, dan cinta damai.

Jika dikaitkan dengan kearifan lokal Kampung Naga di Kabupaten Tasikmalaya, masyarakatnya sangat mencerminkan ketaatan dan menjunjung tinggi nilai-nilai luhur hukum adat. Kearifan lokal masyarakatnya ini sejalan dengan nilai karakter yang termuat pada program Penguatan Pendidikan Karakter. Hal ini bisa dilihat sesuai dengan hasil penelitian sebagai berikut:

a. Religius, merupakan keimanan kepada Tuhan Yang Maha Esa yang ditandai dengan perilaku menjalankan ajaran agama tertentu, toleransi terhadap perbedaan, hidup rukun dan cinta damai. Seluruh masyarakat adat Kampung Naga beragama Islam, ini memiliki keimanan kepada Tuhan Yang Maha Esa.

Dalam kesehariannya, mereka pun menjalankan kegiatan keagamaan sesuai dengan agama yang diyakini, seperti shalat jumat berjamaah, berpuasa, shalat tarawih, pengajian, peringatan hari besar Islam. Akan tetapi, ajaran agama ini masih dipengaruhi pula oleh ajaran kepercayaan leluhurnya. Nilai religius yang dianut oleh masyarakat disini bisa menjadi contoh bagi para peserta didik, khususnya anak-anak yang berasal dari lingkungan Kampung Naga sendiri untuk tetap beriman kepada Tuhan Yang Maha Esa sebagaimana sesuai dengan sila pertama Pancasila Ketuhanan Yang Maha Esa. Sehingga kehidupan religius di masyarakat bisa memperkuat dan membiasakan anak-anak untuk tetap menjalankan ajaran agama sebagai salah satu bentuk Penguatan Pendidikan Karakter.

b. Nasionalis, ditandai dengan setia, peduli, menghargai Bahasa, lingkungan fisik dan sosial, dan cinta tanah air.

Masyarakat disini masih menggunakan Bahasa Sunda asli dengan logat atau lentong yang khas. Dari segi fisik pun masih terlihat sangat mempertahankan ajaran leluhur, seperti bentuk rumah dan pakaian, dari segi kehidupan sosialnya sangat menjunjung tinggi peninggalan ajaran leluhur dan menghormati aturan hukum adat mereka. Sebagai seorang peserta didik, kita tidak harus berprofesi sebagai tantara atau polisi yang melakukan usaha pembelaan negara sebagai bentuk nasionalisme. Akan tetapi, dengan cara menjungjung tinggi aturan hukum dan aturan yang hidup di masyarakat masing-masing juga merupakan contoh perwujudan dari nasionalis tersebut. Seperti masyarakat adat Kampung Naga yang menjungjung tinggi nilai-nilai adat leluhurnya dan tetap mematuhinya samapai saat ini. Perwujudan sikap nasionalis ini diharapkan dapat memperkuat pemahaman peserta didik tentang nasionalisme yang telah didapatkan di bangku persekolahan dan melalui kegiatan pembiasaan di rumah, sekolah, dan lingkungan masyarakat.

c. Mandiri, berupa sikap yang tidak mengandalkan pada orang lain, memiliki daya juang dan etos kerja yang baik.

Kampung Naga tidak menggunakan listrik dalam kehidupan sehari-harinya, meskipun pernah beberapa kali mendapatkan tawaran bantuan dari berbagai pihak untuk pemasangan listrik secara gratis. Mereka beranggapan ingin tetap mempertahankan keaslian budaya mereka dan mencegah kejadian yang tidak diinginkan seperti kebakaran yang pernah terjadi pada zaman dahulu sehingga menghangsukan kitab mereka. Sikap mandiri ini menjadi pendukung Penguatan Pendidikan Karakter yang mengajarkan kepada peserta didik untuk tidak mengandalkan orang lain dan tetap 
mengandalkan kemampuan diri sendiri dan menjunjung tinggi etos kerja yang baik.

d. Gotong royong, mencerminkan semangat bekerja sama, musyawarah mufakat, dan tolong menolong.

Sebagai bangsa Indonesia yang terkenal ramah dan memiliki solidaritas yang tinggi, peserta didik perlu mengimplementasikan nilai-nilai gotong royong atau kerja sama dalam kehidupan sehari-harinya dimulai dari lingkungan terkecil keluarga, sekolah, masyarakat, bangsa dan negara. Nilai-nilai gotong royong yang patut dicontoh dari kehidupan masyarakat adat Kampung Naga adalah mengutamakan kepentingan publik daripada kepentingan golongan atau pribadi. Selain itu, pengambilan keputusan dilakukan dengan cara musyawarah muafakat sebagai perwujudan negara Indonesia yang demokratis berdasarkan Pancasila.

Nilai gotong royong masyarakat adat Kampung Naga juga dapat terlihat dari kebersamaan masyarakatnya dalam mengolah sawah atau lading. Jika musim tanam dan panen, masyarakat akan bekerja sama mengolah sawah tersebut yang pada akhirnya akan ada system pembagian hasil panen. Sebagaimana konsep gotong royong yang dikemukakan oleh Koentjaraningrat (1984) bahwa nilai gotong royong merupakan nilai kehidupan rakyat masyarakat agraris, khususnya masyarakat Jawa dengan melibatkan tenaga tambahan selain keluarga dalam aktivitas bercocok tanam. Begitu pula dalam upacara tolak bala atau salametan ketika menanam padi yang dilakukan bersamasama dipimpin oleh ajengan atau kuncen (Ekadjati, 1984).

e. Integritas, ditandai dengan perilaku yang dapat dipercaya, tanggung jawab, dan aktif dalam kehidupan sosial.

Nilai-nilai kejujuran, tanggung jawab, dan integritas menjadi nilai yang krusial pada masa globalisasi saat ini. Hal ini dikarenakan dampak negatif dari adanya pengaruh paham barat yang lebih mengutamakan liberalism, konsumerisme, kapitalisme, dan hedonisme. Berangkat dari keseharian masyarakat adat
Kampung Naga yang memiliki integritas tinggi, peserta didik bisa menjadi teladan dalam Penguatan Pendidikan Karakter Berbasis Masyarakat, khususnya dalam penanaman dan pembiasaan nilai integritas.

Dengan adanya karakteristik masyarakat adat Kampung Naga yang masih menjunjung tinggi ajaran leluhur dan nilai-nilai kearifan lokal, akan menjadi mitra sekolah yang cocok dalam mewujudkan Penguatan Pendidikan Karakter Berbasis Masyarakat. Hal ini bisa diimplementasikan dengan kegiatan habituasi nilai-nilai dalam keseharian seklah ke lingkungan masyarakat, atau justru mempelajari nilai-nilai karakter yang dianut suatu kelompok masyarakat (Kampung Naga) untuk selanjutnya diimplementasikan dalam kehidupan peserta didik sehari-hari. Perwujudan Penguatan Pendidikan Karakter Berbasis Masyarakat tentunya dengan tetap mendapatkan dukungan dari orang tua dan keluarga serta pelibatan lingkungan masyarakat sekitarnya. Melalui lingkungan orang tua dan kerabat, peserta didik akan memperoleh dasar-dasar pola pergaulan hidup yang benar dan baik, melalui penanaman disiplin dan kebebasan serta penyerasiannya (Soekanto, 2003). Pendekatan berbasis masyarakat sebagaimana dimaksud dapat dilakukan dengan cara (Pasal 6 Permendikbud No. 20 Tahun 2018 tentang Penguatan Pendidikan Karakter pada Satuan Pendidikan Formal):

a. Memperkuat peranan orang tua sebagai pemangku kepentingan utama Pendidikan dan Komite Sekolah sebagai Lembaga partisipasi masyarakat yang menjunjung tinggi prinsip gotong royong;

b. Melibatkan dan memberdayakan potensi lingkungan sebagai sumber belajar seperti keberadaan dan dukungan pegiat seni dan budaya, tokoh masyarakat, alumni, dunia usaha, dan dunia industri; dan

c. Mensinergikan implementasi PPK dengan berbagai program yang ada dalam lingkup akademisi, pegiat Pendidikan, Lembaga swadaya masyarakat, dan Lembaga informasi.

Dengan demikian, masyarakat adat Kampung Naga sangat berpotensi untuk dijadikan mitra skeolah dalam mewujudkan Penguatan Pendidikan Karakter Berbasis 
Volume 12 | Number 1| April |2021, Page 30-36/ E-ISSN: 2715-1247 dan P-ISSN: 2087-84xx

Masyarakat sebagai perpanjangan dari program sebelumnya, yaitu Penguatan Pendidikan Karakter Berbasis Kelas dan Sekolah. Hal ini ditandai dengan masyarakat adat Kampung Naga yang memiliki potensi lingkungan yang dapat dijadikan sumber pembelajaran, adanya dukungan tokoh dan kelompok masyarakat yang mencerminkan nilia-nilai karakter, berada di Kawasan yang mudah akses dan dekat dengan lingkungan persekolahan, memiliki kerjasama dengan pemerintah dan orang tua peserta didik. Keberhasilan Pendidikan karakter harus melibatkan orang dalam dan orang di luar lingkungan sekolah secara optimal, yaitu orang tua atau wali peserta didik dan anggota masyarakat atau komunitas dalam mewujudkan sekolah karakter (Saptono, 2011).

Untuk keberhasilan program Penguatan Pendidikan Karakter Berbasis Masyarakat di Kampung Naga, sekolah sebagai mitra perlu melakukan beberapa langkah awal sebagai berikut:

a. Memberikan pengetahuan dan pemahaman kepada guru, peserta didik, dan masyarakat adat Kampung Naga mengenai rencana program yang akan dilaksanakan;

b. Menyediakan berbagai sarana dan prasarana pendukung untuk keberhasilan program yang optimal;

c. Memberikan sosialisasi dan kesepakatan kerja sama dengan pihak masyarakat adat Kampung Naga;

d. Pemberdayaan peserta didik dan masyarakat adat Kampung Naga; dan

e. Jika program ini telah terlaksana dengan baik, perlu diadakan publikasi program dan impelementasi Penguatan Pendidikan Karakter sebagai bahan evaluasi dan motivasi bagi pihak sekolah atau kelompok masyarakat lainnya.

\section{SIMPULAN}

Dari hasil penelitian dan pembahasan, dapat diperoleh kesimpulan bahwa program Penguatan Pendidikan Karakter Berbasis Masyarakat dilaksanakan sebagai upaya pemantapan dari program Penguatan Pendidikan Karakter Kelas dan Sekolah. Penguatan Pendidikan Karakter Berbasis Masyarakat perlu mendapat dukungan dari orang tua, sekolah, tokoh atau kelompok masyarakat tertentu yang dapat dijadikan mitra kerja. Misalnya masyarakat adat Kampung Naga yang dijadikan mitra sekolah sebagai sumber pembelajaran Penguatan Pendidikan Karakter Berbasis Masyarakat. Hal ini dikarenakan masyarakat adat Kampung Naga yang dianggap memiliki kehidupan yang mencerminkan nilai Penguatan Pendidikan Karakter, diantaranya religius, nasionalis, mandiri, gotong royong, dan integritas. Kelima nilai-nilai karakter tersebut tercermin dalam kehidupan, baik secara fisik, sosial, dan budaya.

\section{DAFTAR RUJUKAN}

Alwasilah, A.C. (2003). Etnopedagogi sebagai Landasan Praktik Pendidikan dan Pendidikan Guru. Bandung: Rizqi Press.

Ekadjati, E. (1984). Masyarakat Sunda dan Kebudayaannya. Jakarta: Girimukti Pasaka.

Koentjaraningrat. (1984). Kebudayaan Jawa. Jakarta: Balai Pustaka.

Kusnaedi. (2013). Strategi dan Implementasi Pendidikan Karakter Panduan Untuk Guru dan Orang Tua. Bekasi: Duta Media Tama.

Miles \& Huberman. (2014). Qualitative Data Analysis, A Methods Sourcebook, Edition 3. USA: Sage Publications.

Peraturan Presiden Republik Indonesia Nomor 87 Tahun 2017 tentang Penguatan Pendidikan Karakter

Permendikbud No. 20 Tahun 2018 tentang Penguatan Pendidikan Karakter pada Satuan Pendidikan Formal.

Saptono. (2011). Dimensi-dimensi Pendidikan

Karakter, Wawasan, Strategi, dan Langkah Praktis. Jakarta: Erlangga.

Soekanto, S. (2003). Sosiologi Suatu Pengantar. Jakarta: Raja Grafindo Persada.

Tilaar. (2000). Paradigma Baru Pendidikan Nasional. Jakarta: Rineka Cipta. 